\title{
ENIGE OPMERKINGEN INZAKE HET AANHANGIG MAKEN VAN ZAKEN IN HET TUCHTRECHT VOOR ACCOUNTANTS
}

\author{
door Mr. H. H. Bos
}

Het volstrekt eigensoortig karakter van het tuchtrecht brengt specifieke problemen met zich mede, welker oplossing niet dadelijk voor de hand ligt. Zo is o.m. het aanhangig maken van tuchtzaken bij herhaling een onderwerp van discussie geweest. Het kan wellicht nuttig zijn hieraan nog een aantal beschouwingen te wijden.

Zowel bij de V.A.G.A. als bij het N.I.v.A. worden tuchtzaken aanhangig gemaakt op klacht of op verzoek van het Bestuur. ${ }^{1)}$ Dat in het tuchtrecht bij verenigingen de natuurlijke klager op de voorgrond treedt, is een gebruikelijk verschijnsel. Behalve een gelaedeerde buitenstaander zal dit een lid van de vereniging kunnen zijn. In ieder geval komt het klaagrecht dus toe aan een belanghebbende. In het algemeen doet het echter niet ter zake van wie een klacht afkomstig is. De bestaande tuchtregeling legt $\mathrm{nl}$. geen enkele beperking aan ten aanzien van de personen, die een klacht kunnen indienen. Ook de motieven, welke tot een bepaalde klacht hebben geleid, zijn in dit verband irrelevant. Het enkele feit, dat door wie dan ook een klacht wordt ingediend, brengt noodzakelijkerwijs behandeling daarvan door de tuchtrechter met zich mede.

Meermalen is de vraag aan de orde geweest of in het tuchtrecht van het N.I.v.A. plaats is voor een openbare aanklager, op gelijke wijze als het O.M. in strafzaken. $\left.{ }^{2}\right)$ Gelet op het feit, dat het tuchtrecht van interne strekking is, is de figuur van een openbare aanklager in de zin van een ambtelijk persoon uiteraard onbestaanbaar. De overheid kan in de interne regeling van een beroepsgroep niet fungeren. Hoogstens zou een officiële namens het beroep optredende en opererende aanklager denkbaar zijn. Het accountantsgilde is, maatschappelijk bezien, echter een beperkt gezelschap. Zolang dit een nog overzichtelijke kring van personen is, doet de behoefte aan een zodanige aanklager zich niet gevoelen. Eerst als de kring te groot en het groepsverband losser zou worden, zou er ten deze een probleem kunnen rijzen. Ook dan is het echter nog de vraag of voor een aanklager als hierbedoeld plaats is.

Naast de natuurlijke klager kan het Bestuur een actieve rol spelen bij het aanhangig maken van tuchtzaken. Hierbij zijn drie mogelijkheden te onderscheiden:

1. bij het signaleren van vermeende tuchtrechtelijke overtredingen, waarbij zich geen natuurlijke klager aandient.

Het belang van het beroep brengt mede, dat alle daarvoor in aanmerking komende overtredingen inderdaad worden berecht. Dat de natuurlijke klager het eerst behoort op te treden is duidelijk. Neemt deze echter om hem moverende redenen geen initiatief, of ontbreekt een natuurlijke klager, dan is het Bestuur het aangewezen orgaan voor het inschakelen van de tuchtrechter. Het Bestuur van het Instituut stelt zich terecht op dit standpunt. ${ }^{3}$ ) Het feit van de over-

1) Bij de V.A.G.A.: art. 5 Reglement van Toezicht; bij het N.I.v.A.: art. 11 Reglement op de Tuchtrechtspraak.

2) Mr A. Th. E. Kastein: „Beschouwingen over de tuchtrechtspraak”, De Accountant, 58e jrg. no. 8 , blz. 14 e.v.

3) „De Accountant” 1945, blz. 15. 
treding en de naam van de betrokken accountant moeten dan natuurlijk aan het Bestuur bekend zijn.

\section{2. bij publicke opspraak van het beroep.}

Uitlatingen van officiële instanties of personen, eventueel middels de pers publiekelijk bekend gemaakt, welke de goede naam van het beroep in opspraak brengen, leggen het Bestuur de plicht op een onderzoek naar de al dan niet juistheid van deze uitlatingen te doen instellen. Dit is een uit de statuten voortvloeiende eis. De hierbedoelde plicht behoort zover te gaan, dat het Bestuur tenminste alle voor een zodanig onderzoek noodzakelijke gegevens bijeenbrengt en aan de tuchtrechter voorlegt.

\section{2. bij publieke opspraak van bet beroep.}

Hierbij moet nog nader onderscheiden worden. Het kan nodig zijn, dat het Bestuur zelf het initiatief neemt voor berechting. Een individueel lid, dat publiekelijk in opspraak is gekomen, kan zich nu eenmaal niet zelf rechtstreeks tot de tuchtrechter richten en een onderzoek naar eigen gedragingen en handelingen vragen. Het Bestuur kan dit wel. Het dient daarmede niet alleen het beroepsbelang, doch het kan tevens de individuele beroepsgenoot hierdoor in bescherming nemen. Het onder punt 2 gestelde geldt mutatis mutandis ook hier, waarbij de plicht van het Bestuur zover behoort te gaan, dat het in voorkomende gevallen ook de identiteit van de in opspraak gebrachte beroepsgenoot vaststelt. Het vaststaan van de identiteit is immers een voorwaarde voor de berechting. Het andere geval is, dat een publiekelijk in opspraak gebrachte beroepsgenoot zich tot het Bestuur wendt met het verzoek zijn zaak ter berechting aan de tuchtrechter voor te leggen. Het behoeft geen betoog dat het Bestuur een zodanig verzoek op gelijke gronden als het hierboven gestelde geval nier kan weigeren. De zaak wordt dan indirect door het Bestuur aan de tuchtrechter voorgelegd.

Een geheel afzonderlijk probleem is de vraag of de tuchtrechter al dan niet bevoegd moet zijn ambtshalve onderzoekingen in te stellen. Uit de geschiedenis van de N.I.v.A.-tuchtrechtspraak blijkt, dat deze mogelijkheid gedurende 38 jaren heeft bestaan, nl. van 1895-1933. In de opeenvolgende reglementen op de tuchtrechtspraak heette het, dat de tuchtrechter ,ambtshalve”, ,ex officio" of „,uit eigen beweging" een onderzoek kon instellen. ${ }^{4}$ ) Grosheide heeft de ,aanval” op deze situatie ingezet. In stelling 10 van zijn referaat voor een studievergadering in 1932 sprak hij als zijn oordeel uit het niet juist te achten, dat de tuchtrechter ambtshalve tot het instellen van onderzoeken kan overgaan. ${ }^{5}$ ) De kort daarop gevolgde reglementsherziening gaf een principiële wijziging van de tuchtregeling van het N.I.v.A. te zien: zonder enige discussie werd het „ambtshalve”-onderzoek geschrapt.

Na deze wijziging in 1933 is het probleem zelf nog bij herhaling in discussie geweest. O.m. in 1952, toen Kastein in een studievergadering in stelling 5 van zijn referaat betoogde, dat de taak van de tuchtrechter zich in de eerste plaats dient te beperken tot de rechtspraak. Uit dien hoofde achtte hij het minder gewenst de

4) Zie laatstelijk: Reglement op de tuchtrechtspraak van 15 juli 1928, art. 6. Tussen 1895 en 1933 ziin van de 42 behandelde tuchtzaken in totaal $6(14,3 \%)$ ex officio onderzocht.

5) „De Accountant” 1932, blz. 166, 186, 214-216. 
„opsporing” aan de tuchtrechter toe te delen. ${ }^{6}$ ) Voorts sprak Moret, in een nota naar aanleiding van een reglementsherziening in datzelfde jaar als zijn oordeel uit, dat het onwenselijk is, dat de tuchtrechter zelf het initiatief neemt om tegen leden van de vereniging op te treden, omdat hij dan in eigen zaak vonnis zou wijzen. ${ }^{7}$ )

$\mathrm{Nu}$ het Wetsontwerp „Regelen betreffende het accountantswezen” de mogelijkheid van het ambtshalve onderzoek weer openstelt (art. 40, lid 1) is de vraag gewettigd of dit juist is. Ik meen, dat daartegen twee belangrijke bezwaren zijn aan te voeren.

Een ambtshalve onderzoek brengt met zich mede, dat daaraan is verbonden het toezicht op de handelingen en gedragingen van de beroepsbeoefenaren. Onder toezicht versta ik hier het doelbewust continu controleren. ${ }^{8}$ ) Dit zou betekenen, dat de tuchtrechter zich onafgebroken zekerheid zou moeten verschaffen omtrent de gedragingen van degenen, die aan het toezicht onderworpen zijn. Het uitoefenen van zodanig toezicht zal echter uiterst moeilijk zijn. Het Bestuur heeft bij de afschaffing van het ambtshalve onderzoek in 1933 zelf reeds uitgesproken, dat een afdoend toezicht onmogelijk is. $\left.{ }^{9}\right)$ Daarbij komt nog, dat de reglementen dit toezicht ook niet aan de tuchtrechter hebben toebedeeld. In het wetsontwerp voornoemd is dit evenmin het geval. Verenigingsrechtelijk behoort het toezicht bij het Bestuur als het centrale en leidinggevende orgaan van de organisatie. De enige reglementaire bevoegdheid van de tuchtrechter is: onderzoeken en beslissen (art. 1 Reglement op de tuchtrechtspraak).

Een tweede bezwaar is, dat een ambtshalve onderzoek de tuchtrechter in juridische zin niet kan toekomen. Een tuchtcollege is cen rechtsprekend orgaan. Indien de taak van de ,opsporing” aan dit college mede zou worden toebedeeld, zou dit afbreuk doen aan de objectiviteit van de tuchtrechtspraak. De beroepsgenoten moeten in voorkomende gevallen en onbevooroordeelde berechting kunnen verwachten. Daarmede verdraagt zich niet, dat de rechter tegelijkertijd fungeert als aanklager.

Op grond van de hierboven genoemde bezwaren moet ik concluderen, dat een wederinvoering van een ambtshalve onderzoek geredelijk aanleiding zal kunnen geven tot een ondermijning van het vertrouwen in de tuchtrechtspraak. In wezen zouden daardoor de grondslagen van de verenigingstuchtrechtspraak worden aangepast. De rechtsprekende functie van de tuchtrechter sluit iedere andere functie uitdrukkelijk uit. Dat het ambtshalve onderzoek in het N.I.v.A.-tuchtrecht bestaanbaar is geweest, is alleen historisch te verklaren. Oorspronkelijk fungeerde immers het Bestuur tevens als Raad van Tucht, en nog lang daarna heeft deze situatie doorgewerkt. Slechts daar, waar toezicht en rechtspraak in handen van één orgaan is - terecht of ten onrechte -, is plaats voor een ambtshalve onderzoek. ${ }^{10}$ )

Het komt mij voor, dat bij het tuchtrecht voor accountants een volledige scheiding tussen ,opsporing" en rechtspraak noodzakelijk is, zulks in overeenstemming met de thans bestaande situatic. Hoe de wetgever zich de regeling van het ambts-

6) t.a.p. blz. 4 .

7) „De Accountant” 1952/53, blz. 635 .

8) Zie hierover, in verband met het ontwerp wettelijke regeling in 1939: Mr. M. van Regteren Altena "De tuchtrechtspraak en het ontwerp wettelijke regeling van het accountantswezen", M.A.B. 1939, blz. 147.

9) "De Accountant", 1933, no. 6 blz. 13/14.

10) "Zo bijv. Notariswet, art. 50; ook verenigingstuchtrechtspraak der Kon. Mij. tot bevordering van de Geneeskunst, Huishoudelijk Reglement art. 604. De geneeskundigen zijn echter ook aan overheidstuchtrecht onderworpen.

$\mathrm{m}$ a b blz. 60 
halve onderzoek voorstelt is mij voorshands niet duidelijk. M.i. zou het een stap terug betekenen in de ontwikkeling van de tuchtrechtspraak.

Tot slot van bovenstaande beschouwing wil ik nog op de bijzondere betekenis van het klaagrecht van de particuliere aanklager wijzen. In 50 jaren tuchtrechtspraak van het N.I.v.A. (1895-1945) telde ik 93 in eerste aanleg aanhangig gemaakte tuchtzaken. Hiervan werden er $68(73 \%)$ op klacht behandeld, 19 $(20,5 \%)$ op verzoek van het Bestuur en $6(6,5 \%)$ ambtshalve. In de praktijk treedt ook in het accountantstuchtrecht de natuurlijke klager dus wel zeer op de voorgrond. 